\title{
Decrease Blood Pressure on Hypertensive Patients with Mediterranean Diet
}

\author{
Endry Septiadi* \\ Department of Nutrition, Faculty of Medicine \\ University of Jenderal Achmad Yani \\ Cimahi, Indonesia \\ *endry.septiadi@lecture.unjani.ac.id
}

\author{
Andri Andrian Rusman \\ Department of Forensic, Faculty of Medicine \\ University of Jenderal Achmad Yani \\ Cimahi, Indonesia
}

\author{
Achmad Hero Prawira, Rifal Aldi Anugrah, Nur Muhamad Rohman, Muhammad Akmal Rais, M. Arasy Faradina, \\ Reza Fadhil Nugraha \\ General Medicine Study Program, Faculty of Medicine \\ University of Jenderal Achmad Yani \\ Cimahi, Indonesia
}

\begin{abstract}
Hypertension is a disease with an increasing number of sufferers every year. To control and lower blood pressure in hypertensive patients, pharmacological and nonpharmacological therapies are needed. Non-pharmacological hypertension therapy can be done by modifying the diet, one of which has been recommended by the American Heart Association (AHA) is the Mediterranean diet. The composition of the Mediterranean diet contains high levels of PUFA, MUFA, and antioxidants that can lower blood pressure sourced from vegetable and olive oil. The design of this study used an analytical method with a cohort observation of 63 hypertension subjects with a Mediterranean diet. This study aims to determine the correlation between the duration of the Mediterranean diet on systolic and diastolic blood pressure in hypertensive patients. Researchers divided the three groups based on the length of the diet in three months. Systolic and diastolic blood pressure data were analyzed using the Anova test and Duncan's Post Hoc comparison test. The results of this study found a significant relationship with a value of $p=0.001$ in the decrease in systolic blood pressure, and $p=0.010$ for the decrease in diastolic blood pressure. The Mediterranean diet lowers blood pressure by improving endothelial dysfunction, suppressing oxidative stress, and improving the renin-angiotensin-aldosterone system. In this study, it can be concluded that there is a significant decrease in blood pressure in hypertensive patients who are running the Mediterranean diet.
\end{abstract}

Keywords—blood pressure, diastolic, mediterranean diet, systolic

\section{INTRODUCTION}

Hypertension is defined as an increase in systolic blood pressure of more than $140 \mathrm{mmHg}$ and/or diastolic blood pressure of more than $90 \mathrm{mmHg}$ on two measurements with an interval of five minutes in a state of rest and calm [1]. In 2015, the World Health Organization (WHO) said that around 1.13 billion people in the world have hypertension [2]. Data from Riskesdas 2013 in Indonesia, the prevalence of hypertension reached $25.8 \%$, and this figure increased in 2018, namely $34.1 \%$ [3]. Management of hypertension can be done by using drugs or by modifying lifestyle. Lifestyle modification becomes non-pharmacological management in hypertensive patients. One of the lifestyle modifications recommended by the American Heart Association (AHA) is the Mediterranean $\operatorname{diet}[4,5]$.

The Mediterranean diet is a diet practiced by people around the Mediterranean Sea that has been studied to have a lower risk of heart disease [6]. The Mediterranean diet is high in monounsaturated fatty acids (MUFA) from nuts and olive oil, polyunsaturated fatty acids (PUFA) from fish and seafood, and antioxidants from fruits and vegetables, which can improve endothelial function to reduce pressure. blood in hypertensive patients [7-11].

Research conducted by Courtney R Davis et al. 2017 stated that the Mediterranean diet significantly lowers systolic blood pressure. The effect of high MUFAs is to reduce the susceptibility of cholesterol molecules to oxidation which can reduce free radicals which decrease the vasodilator effect [10]. Another effect is that antioxidants can inhibit free radical damage that can initiate and develop into atherosclerosis. The benefits of the Mediterranean diet contribute to the prevention of hypertension and as an alternative to non-pharmacological nutritional therapy to lower blood pressure in hypertensive patients, so this study aims to determine the effect of the Mediterranean diet to lower blood pressure in hypertensive patients as a non-pharmacological management option for hypertensive patients. 


\section{METHODS}

The design of this study was an analytical method to determine the long-standing relationship of the Mediterranean diet with blood pressure in hypertensive patients. This study conducted a cohort observation of hypertensive patients on a Mediterranean diet for three months. Sampling using a consecutive sampling technique. 63 patients were consisting of men and women aged $\geq 35$ years who were undergoing a Mediterranean diet. The research group was divided according to the length of doing the Mediterranean diet, namely the onemonth group (K1), the two months' group (K2), and the three months' group (K3). Patients who undergo a Mediterranean diet are identified with the Mediterranean Diet Adherence Screener (MEDAS) [12] and blood pressure checks using a digital sphygmomanometer. All patients scored more than nine and thus defined a Mediterranean diet. The questionnaire was administered using a food model assistive instrument to determine the portion size or serving per question item.

The data obtained were edited, verified, coding, and data entry, then data analysis was carried out. The data measurement scale is numerical, so it is necessary to conduct a descriptive analysis of the data to determine the average blood pressure value in each group. Blood pressure data was then carried out by the Kolmogorov Smirnov normality test and the Levene homogeneity test, both of which showed a $p$ value> 0.05 defined as a normal and homogeneous distribution of data. The data analysis was then analyzed by using the Anova test and followed by Duncan's Post Hoc test. The significance criterion used was a p-value $<0.05$, which means it is significant or statistically significant. Data analysis used the SPSS version 23 statistical program.

\section{RESULTS}

Analysis of systolic and diastolic blood pressure data at K1, $\mathrm{K} 2$, and K3 was carried out by the Kolmogorov Smirnov normality test and Levene's homogeneity which showed p> 0.05 so that the statistical analysis was continued with the Anova and Post Hoc Duncan tests to determine the relationship between the length of the Mediterranean diet and blood pressure at hypertensive patients.

TABLE I. DISTRIBUTION OF MEAN BLOOD PRESSURE REDUCTION BASED ON LENGTH OF THE MEDITERRANEAN DIET

\begin{tabular}{|c|c|c|c|c|c|c|}
\hline Variable & Group & $\mathbf{N}$ & $\begin{array}{c}\text { Mean } \\
(\mathrm{mmHg})\end{array}$ & SD & $\begin{array}{c}\mathbf{F} \\
\text { (Anova) }\end{array}$ & $\begin{array}{c}\text { P- } \\
\text { Value }\end{array}$ \\
\hline \multirow{3}{*}{$\begin{array}{l}\text { Systolic } \\
\text { Blood } \\
\text { Pressure } \\
\end{array}$} & K1 & 21 & 3,90 & 14,28 & \multirow{3}{*}{7,885} & \multirow{3}{*}{0,001} \\
\hline & $\mathrm{K} 2$ & 21 & 10,04 & 8,26 & & \\
\hline & K3 & 21 & $19,09^{*}$ & 13,93 & & \\
\hline \multirow{3}{*}{$\begin{array}{l}\text { Diastolic } \\
\text { Blood } \\
\text { Pressure }\end{array}$} & K1 & 21 & 4,80 & 7,63 & \multirow{3}{*}{4,959} & \multirow{3}{*}{0,010} \\
\hline & $\mathrm{K} 2$ & 21 & 6,90 & 7,31 & & \\
\hline & $\mathrm{K} 3$ & 21 & $11,52^{*}$ & 6,16 & & \\
\hline
\end{tabular}

$(*)=$ significant (Duncan's Post Hoc, subset for alpha $=0,05$ )

\section{A. The Mediterranean Diet Decreases Systolic Blood Pressure}

Table 1 shows the average reduction in systolic blood pressure at $\mathrm{K} 1$ is $3.90 \mathrm{mmHg}$ with a standard deviation of 14.28. The average decrease in $\mathrm{K} 2$ was $10.04 \mathrm{mmHg}$ with a standard deviation of 8.26 , and in $\mathrm{K} 3$ the mean decrease was $19.09 \mathrm{mmHg}$ with a standard deviation of 13.93 . The decrease in systolic blood pressure in the three groups statistical results obtained p-value $=0.000$ which means there is a significant decrease. This statistical value shows that the length of time on the Mediterranean diet has the potential to reduce systolic blood pressure. The analysis was continued with Duncan's Post Hoc comparative test, which shows the results in Table 1 that there is a significant difference in the decrease in systolic blood pressure at $\mathrm{K} 3$ between $\mathrm{K} 2$ and $\mathrm{K} 1$. The mean reduction in systolic blood pressure in $\mathrm{K} 3$ was greater than $\mathrm{K} 2$ and $\mathrm{K} 2$ was greater than K1. The decrease was spread and statistically significant for other groups was K3 with an average of 19.09 $\mathrm{mmHg}$. So it can be interpreted that the three-month Mediterranean diet affects reducing systolic blood pressure.

\section{B. The Mediterranean Diet Decreases Diastolic Blood Pressure}

Diastolic blood pressure is shown in Table 1, mean K1, there is a decrease of $4.80 \mathrm{mmHg}$ with a standard deviation of 7.63. The mean reduction in $\mathrm{K} 2$ was $6.90 \mathrm{mmHg}$ with a standard deviation of 7.31. The decrease in diastolic blood pressure at $\mathrm{K} 3$ a mean of $11.52 \mathrm{mmHg}$ with a standard deviation of 6.16. The P-value obtained was $\mathrm{p}=0.000$, which means a significant decrease in diastolic blood pressure in the three groups. Followed by the Post Hoc Duncan comparative test on the decrease in diastolic blood pressure in Table 1 shows the largest decrease in K3, namely $11.5238 \mathrm{mmHg}$. The decrease in blood pressure in $\mathrm{K} 3$ is greater than that of $\mathrm{K} 2$ and $\mathrm{K} 2$ is greater than that of $\mathrm{K} 1$. A significant decrease occurred between $\mathrm{K} 3$ and $\mathrm{K} 2$, and $\mathrm{K} 3$ with $\mathrm{K} 1$, but $\mathrm{K} 2$ and $\mathrm{K} 1$ were not significant. The results of Duncan's Post Hoc test showed that the three-month Mediterranean diet had the most effect on the reduction of diastolic blood pressure.

\section{DISCUSSION}

The Mediterranean diet can lower systolic blood pressure by improving the tone of blood vessel walls to reduce arterial stiffness. The Mediterranean diet containing omega-3 can reduce arterial stiffness which is influenced by vasomotor activation, to stimulate the muscle tone of blood vessels which causes vasodilation, thereby reducing peripheral resistance to lowering systolic blood pressure [13]

Reduce the state of inflammation and endothelial dysfunction associated with lowering systolic blood pressure. A Mediterranean diet that is high in omega-3s and antioxidants can inhibit the release of inflammatory markers, thereby suppressing oxidative stress and thus improving endothelial dysfunction $[14,15]$. 
Low glycemic index on the Mediterranean diet, so can contribute to the decreased sympathetic activity, to reduce cardiac contractility and peripheral resistance. Decreased cardiac contractility will affect decreasing cardiac output. Sympathetic activity is closely related to the RAAS system. The Mediterranean diet can improve the RAAS system through decreased sympathetic activity, oxidative stress, and C-reactive protein (CRP). This will inhibit the release of renin so that the change from angiotensin I to angiotensin II can be reduced. Decreased formation of angiotensin II, which is a vasoconstrictor, can reduce peripheral resistance so that systolic blood pressure can decrease [16-18].

The decrease in diastolic blood pressure is influenced by peripheral resistance and stiffness of the large blood vessels [19]. Diastolic blood pressure will decrease with decreasing peripheral resistance and in the case of blood vessels that do not lose elasticity [20]. A Mediterranean diet that is high in MUFAs contained in olive oil can suppress oxidative stress, then antioxidants inhibit the damage that can lead to endothelial dysfunction, thereby reducing peripheral resistance and reducing arterial stiffness [10,21].

Diastolic blood pressure is also affected by preload. Increased preload due to excessive sympathetic activity resulting in increased diastolic blood pressure. A Mediterranean diet that is low on the glycemic index can decrease sympathetic activity to decrease preload. The decrease in sympathetic activity affects the decrease in the RAAS system so that the release of renin is inhibited. The reduced release of renin from the juxtaglomerular can reduce the formation of aldosterone which causes reduced salt reabsorption so that sodium retention is decreased. This is balanced by a Mediterranean diet that is low in sodium to reduce sodium resistance and reduce fluid volume. This mechanism can reduce preload so that diastolic blood pressure decreases $[17,18,22]$

\section{CONCLUSION}

The Mediterranean diet can lower both systolic blood pressure and diastolic blood pressure. The group of patients who followed the Mediterranean diet for three months had the most significant reduction in the other two groups.

\section{ACKNOWLEDGMENT}

In preparing this scientific article, it is inseparable from assistance, advice, and guidance from various parties, therefore on this occasion, the author would like to thank the Dean and staff of the Faculty of Medicine, General Achmad Yani University, research staff who always assist in examination activities, All hypertensive patients in the clinical prolanis community where the research was willing to be the subject of research, parents, and friends who always informed me in completing this scientific article.

\section{REFERENCES}

[1] Pusat data dan informasi Kemenkes RI. Infodatin Hipertensi. (Pusdatin). Jakarta. 2014

[2] World Health Organization (WHO), "Hypertension," [Online] Retrieved from https://www.who.int/news-room/factsheets/detail/hypertension\#.XjjvR5YztQ.mailto

[3] Badan Penelitian dan Pengembangan Kesehatan Kemenkes RI, Hasil Utama RISKESDAS 2018. Jakarta, 2018.

[4] P. Kokkinos, D.B. Panagiotakos, and E. Polychronopoulos, "Dietary influences on blood pressure: the effect of the Mediterranean diet on the prevalence of hypertension," J Clin Hypertens (Greenwich), vol. 7, no. 3, pp. 165-72, 2005

[5] J.L. Boucher, "Mediterranean eating pattern," Diabetes Spectr., vol. 30, no. 2 , pp. 72-6, 2017

[6] Nutrition clinics for UW Medical Foundation, "Mediterranean Food Guide," [online]. Retrieved from https://www.uwhealth.org/healthfacts/nutrition/410.pdf

[7] Advance Genomic Made Personal, "Mufa VS. Pufas," [online] Retrieved from www.ags-health.com

[8] E. Sikora, E. Cieślik, and K. Topolska, "Sources of natural antioxidants Antioxidants Food. Acta Scientiarum Polonorum," Technologia Alimentaria, vol. 7, no. 1, pp. 5-17, 2008.

[9] L.A. Ferrara, A.S. Raimondi, L. D’Episcopo, L. Guida, A. Dello Russo, and T. Marotta, "Olive oil and reduced need for antihypertensive medications,” Arch Intern Med., vol. 160, no. 6, pp, 837-42, 2002.

[10] C.R. Davis, J.M. Hodgson, R. Woodman, J. Bryan, C. Wilson, and K.J. Murphy, "A Mediterranean diet lowers blood pressure and improves endothelial function: Results from the MedLey randomized intervention trial," Am J Clin Nutr., vol. 105, no. 6, pp. 1305-13, 2017

[11] K.S. Reddy and M.B. Katan, "Diet, nutrition and the prevention of hypertension and cardiovascular diseases," Public Health Nutr, vol. 7 , no. 1a, pp. 167-86, 2004.

[12] M.A. Martínez-González, A. García-Arellano, E. Toledo, J. SalasSalvadó, P. Buil-Cosiales, and D. Corella, "A 14-item mediterranean diet assessment tool and obesity indexes among high-risk subjects: The PREDIMED trial," PLoS One, vol. 7, no. 8, 2012.

[13] J.J. Jones and R.J. Mcdowall, "Activity of the vasomotor centers," Circ Res., vol. 5, no. 5, pp. 472-7, 1957.

[14] C. Chrysohoou, D.B. Panagiotakos, C. Pitsavos, U.N. Das, and Stefanadis, "Adherence to the Mediterranean diet attenuates inflammation and coagulation process in healthy adults: The ATTICA study," J Am Coll Cardiol, vol. 44, no. 1, pp. 152-8, 2004

[15] L.J. Appel, F.M. Sacks, V.J. Carey, E. Obarzanek, J.F. Swain, and E.R Miller, "Effects of protein, monounsaturated fat, and carbohydrate intake on blood pressure and serum lipids: Results of the OmniHeart randomized trial," J Am Med Assoc., vol. 294, no. 19, pp. 2455-64, 2005

[16] A. Tuttolomondo, I. Simonetta, M. Daidone, A. Mogavero, A. Ortello, and A. Pinto, "Metabolic and vascular effect of the mediterranean diet," Int J Mol Sci., vol. 20, no. 19, 2019

[17] S. Delacroix and R.G. Chokka, "Hypertension: Pathophysiology and Treatment," J Neurol Neurophysiol, vol. 05, no. 06, 2014.

[18] G. Beevers, Y.H. Gregory, and E.O. Lip, “ABC of hypertension: The pathophysiology of hypertension,” BMJ J, vol. 322, pp. 912-6, 2001

[19] J.G. Wang, J.A. Staessen, S.S. Franklin, R. Fagard, and F. Gueyffier, "Systolic and diastolic blood pressure lowering as determinants of cardiovascular outcome," Hypertension, vol. 45, no. 5, pp. 907-13, 2005.

[20] F.P.S.G. de, "Systolic, diastolic and pulse pressure: pathophysiology," Ital Heart J Suppl., pp. 359-62, 2001.

[21] T. Psaltopoulou, A. Naska, P. Orfanos, D. Trichopoulos, T Mountokalakis, and A. Trichopoulou, "Olive oil, the Mediterranean diet, and arterial blood pressure: the Greek European Prospective Investigation into Cancer and Nutrition (EPIC) study," Am J Clin Nutr., vol. 80, no. 4, pp. 1012-8, 2004.

[22] W. Kopp, "Chronically increased activity of the sympathetic nervous system: Our diet-related "evolutionary" inheritance," J Nutr Heal Aging, vol. 13 , no. 1 , pp. $27-9,2009$ 